\title{
Approaches to Composition Writing: The Case of Junior Secondary Schools in Botswana
}

\author{
Deborah Adeninhun Adeyemi \\ University of Botswana, Gaborone, Botswana
}

E-Mail: adeyemid@mopipi.ub, Fax: (267) 3185096

Accepted: November 20, 2011 Published: January 02, 2012

Doi:10.5296/ijld.v2i1.1218ＵRL: http://dx.doi.org/10.5296/ijld.v2i1.1218

\begin{abstract}
This investigation aims at identifying the approaches teachers in junior secondary schools utilize in the teaching of English composition writing and assesses how far the approaches impact students' development of effective writing skills. It also discusses the challenges/advantages posed by the use of such approaches in writing pedagogy. The study utilizes the qualitative technique through interviews, observations, literature reviews, examination of documents and students' artifacts. Based on the methodologies employed, the major findings are that teachers mainly used the product oriented approach to teaching composition writing. As a result of the approach, the teachers were confronted with students' inability to write in any meaningful way as a result of surface level errors, lack of ideas/vocabulary, lack of organization skills and students' inability to compose effectively among other problems. On the part of students, they were found to have poor writing skills reflected in their inability to compose, lack of ideas and vocabulary and general apathy to composition writing which is a disadvantage if students are to become effective communicators in an increasingly globalized world.
\end{abstract}

Key Words: $\quad$ Product writing, process writing, reading/writing connection, modeling.

\section{Introduction}

Botswana is situated in Southern Africa. Botswana which was formerly known as the Bechuanaland Protectorate became independent in 1966. The country was ruled by the British between 1885 and 1965. As a result of her past colonial contact with Britain, English is very important in the country. It is an official language and a medium of instruction in schools and 
institutions of higher learning. It is also a major language of communication within the country, the Southern African region of which Botswana is a member, the continent of Africa and globally.

After independence, efforts were made through various education policies to enhance the teaching and learning of the English language in Botswana, Republic of Botswana (1977; 1994). These documents envisioned the effective preparation of students for life, citizenship and world of work. In addition, current trends dictate the necessity for highly proficient skills in English which has become a globalized language. Mckay (2004) states that currently in many countries, there is a tremendous pressure to learn English. This has resulted in some previously conservative countries such as China and Japan encouraging their citizens to develop English speaking and writing skills.

In the national document, Vision 2016- A Long Term Vision for Botswana (Republic of Botswana, 1997), communication is prioritised as the citizens are envisioned as an, 'educated and informed nation by the year 2016.' A pertinent paragraph says:

Botswana will have entered the information age on an equal footing with other nations. The country will have sought and acquired the best available information technology, and have become a regional leader in the production and dissemination of information (Republic of Botswana, 1997:5).

Furthermore, Recommendation 31 of the Revised National Policy on Education (RNPE) (Republic of Botswan, 1994) emphasises proficiency in the use of English, as a tool for effective communication, study and work, as well as an important goal of Junior Secondary Certificate (JC) curriculum (Republic of Botswana, 2008). This being the case, there is tremendous pressure on the students of junior secondary schools to develop competency and basic communication skills in the English language.

Finally, the importance and use of English across the entire school curriculum cannot be over-emphasised. As well as being an official language in Botswana and in most of the countries in the Southern African region, it is also a major language of communication and commerce, not only internally, but regionally and in the wider global context. It is also an access language in technology and information services. In addition, it facilitates the acquisition, creation and documentation of knowledge (Republic of Botswana, 2002).

\section{Problem Statement}

Competency in English is important in the educational system and in socio-economic terms in Botswana as already explained. It also follows that there are great educational advantages in learning literacy and other skills in English. Prophet (1990:115) argues that "competence in English is important for ensuring access to high status jobs and upward social mobility." Besides, the use of English nationally in education, business and socially has not diminished. In fact, for many African countries, including Botswana, the inability to develop the local 
languages as a result of lack of resources, and other logistical problems has made the learning of English language much more imperative.

Teachers of English in Botswana face many challenges in their effort for effective literacy instruction, most importantly, in the teaching and learning of the English language. A feature of their professional experience as teachers of English as a second language (ESL) is their struggle with the problem of students' inability to do any meaningful form of continuous writing, especially, at the junior secondary level in Botswana. In order to address some of the challenges, the current Junior Secondary English Syllabus (Republic of Botswana, 2008: iii) details the objectives and expected outcomes of the teaching and learning of the English language as follows:

- Communicate accurately, appropriately and effectively in speech and writing both in and outside of school;

- Understand and respond to what they hear, read and experience in a range of situations, settings and media.

- Enjoy reading a range of literature, not only fiction but also general interest works and materials.

- Convey information in logical order and present facts and ideas based on the subjects of the curriculum; and

- Recognize and use different registers, implicit meaning and non-verbal communication appropriate to the situation. Republic of Botswana

The above five outcomes are directly linked to the development of language skills which include the ability to write effectively. However, literature and experience of the researcher as a teacher of English for over one and a half decades indicate that both teachers and students face problems in the teaching and learning of English and especially, composition writing at the junior secondary level. It is also observed that the difficulties have been persistent over the years. In fact, there is continued noticeable poor performance of students in written English as highlighted by various government documents such as:

1. The annual report of the Junior Certificate (JC) English Examination (Republic of Botswana, 2001), commented on the poor performance of students in writing, and recommended among other measures that:

a) Teachers expose learners to varied reading materials and topics in order to enhance their creativity, develop vocabulary and generally enhance languages acquisition and learning.

b) Teachers equip the learners with all the sub-skills of writing, giving lots of practice.

2. The Botswana Ministry of Education Report of the Junior Certificate for English Paper Two

(2) (Republic of Botswana, 2005), which consists of composition and letter writing, notes that some centres attained a pass rate of just below 50\%. This was explained as a result of persistent errors arising from the problem of limited vocabulary and presumably, lack of exposure to wider reading. 
3. The Junior Certificate Examination marking report for Paper Two (2) (Republic of Botswana, 2008) claims that 'Question One' which was the essay was a challenge to many students. It went on to explain that there were many reports received from different teams to indicate that many candidates registered zeros in the essay question and that the candidates could hardly express themselves and that their vocabulary was limited. This was yet another attestation to the poor development of writing skills by the junior secondary level students. These developments are a cause for concern if the aims of basic education and social goals of the country are to be attained as enumerated earlier on.

4. For example, the 2008 Junior Certificate Examination (JCE) report observes that the general performance of students in composition and letter writing has slightly gone down. It is believed that an important factor in students' inadequate writing ability is the entry-level competence of Standard Seven School leavers admitted to form one of junior secondary schools. For example, a survey project report of the learning achievement of Standard Four Pupils produced by the Botswana Ministry of Education (Republic of Botswana, 2001) indicates that, even at the primary school level, only $21.9 \%$ of the pupils tested reached the competency level in literacy in English domains. Actually, for composition writing, the percentage competence was $7.2 \%$. Rowell (1991) points out that teachers and administrators in Botswana have made frequent references to inadequacies of students' written English by the time they enter form one of junior secondary schools. It is believed that the inability of students to develop composition writing skills at the earliest stages of education, has contributed in no small measure to poor performance in writing through junior secondary school, and consequently, beyond that level.

Mooko (1996) elaborates on the problems encountered in the ways composition writing is taught in schools in Botswana, and the fact that students are not given enough writing practice. Fuller and Snyder (1990) observe in their classrooms study of writing in Botswana that, only one percent $(1 \%)$ of the time allocated to English in primary and secondary classrooms was devoted to writing essays. They also noted that although teachers consistently assigned written work, only a small proportion was devoted to writing short essays in class. Rowell (1991) concludes that junior secondary students are not given adequate instruction on composition writing and reports that her study revealed that instances where students were given the opportunity to write paragraphs and compositions were quite rare.

\section{Research Objectives}

The following are the research objectives for this paper:

1. To find out the approaches utilized by teachers in the teaching and learning of English composition writing in a classroom situation;

2. To identify the challenges posed by the use of such approaches in the teaching and learning of English composition writing in the classroom context; and

3. To discuss the challenges identified above. 


\section{Methodology}

\section{Data collection methods and analysis}

The study adopted the qualitative approach using a variety of methods or triangulation. These included observations, interviews, examination of school documents such as syllabus, teachers' lesson plans, marking rubrics, students' artifacts and the use of observation and assessment protocols over a period of one school term of approximately twelve weeks.

The strategies employed in the study included the use of interviews conducted with teachers and students. Purposive sampling was used for the choice of three junior secondary schools, thereby enabling the advantage of targeting those informants whose information might apply to a majority of similar settings in other locations, in this case, other schools and classes in the locality. Field notes were gathered by conducting an observation of three different teachers and 101 students in a natural classroom setting in the role of a non-participant observer for one school term of about thirteen weeks. One-on-one open-ended semi-structured interviews were conducted with the participating teachers and students, combined with the examination of students' artifacts, such as their draft compositions, brainstorming efforts, composition writing exercise books/artifacts. The teachers' lesson plans, marking rubrics and textbooks used by both the students and the teachers were examined where applicable. The field notes made during observations, interviews, examination of documents, notes and students' artifacts were then categorized for analysis in line with the research questions from which conclusions were drawn for discussion and recommendations made.

\section{Literature Review}

The literature reviewed for this study included issues such as the problems of ESL writing, the product and the process approaches to composition instruction and issues of writing at the secondary school level. Furthermore, the different dimensions to the role of the teacher in the students' writing skills development and assessment and their implications in writing instruction were reviewed. These reviews were critically examined with a view to identifying the sources of most students' lack of effective writing skills.

\section{The Difficulties of L2 language Teaching and Learning.}

The differences between the processes of mother tongue (L1) acquisition and the second language (L2) learning have been well documented. The mother and immediate family initially play a critical role in the child's acquisition of (L1), and then the peer group plays the next crucial role, Pongweni (1999). Lyons, (1981:233) asserts that, 'The native speaker's knowledge of their language is a set of rules which they have constructed by virtue of an innate capacity for language-acquisition to the language data that they have heard around them in childhood. This implies that all babies do have an innate ability to learn language in addition to external stimuli they receive from family and peer group.

In contrast to the L2 user's language behaviour, the L1 speaker creatively uses the productivity of the language system largely unconsciously or effortlessly (Lyons, 1981). The L2 speaker on 
the other hand is at a disadvantage because they are learning the language (English) as a second or probably, third language (Honey, 2000) and may not have the ability to exploit the creativity of the target language effectively and as such will have to make a conscious and laborious effort to learn the target language.

In the African context in general, and in Botswana in particular, there is the indication that the appropriate enabling environment for learning English (L2) as indicated by Pongweni (1999) cannot be guaranteed. This is because the teacher cannot rely on the community to reinforce the English language learning adequately. Also, the average parent's unfamiliarity with English and probably the child's own lack of confidence and other socio-economic factors that may hinder the child's exposure to the language may become a hindrance. Also, the competency limitations of the teacher, who is equally an L2 learner of the English language, may be an additional impediment.

\section{Product Writing}

Traditional approaches to writing instruction focus on written products. Teachers evaluate the written product, judge its form and content, according to set criteria. It was also traditionally believed that writing was something that teachers expected learners to do in class without giving any prior thought to the meaning of the finished product (Meriwether, 1997). Williams (2003:2) argues that the product approach is, 'Mindless, repetitive, anti-intellectual'. Again, Escholz (1980) says that the approach merely resulted in mindless copies of a particular organizational plan or style. Silva (1993) dubs it as, 'an exercise in habit formation.' All these assertions on the product paradigm is rooted in the behavourist theory which sees language as a system of structurally related elements for the coding of meaning, and the product of language learning being the mastery of elements of this system (Richards and Rodgers, 1995). This view probably accounts for the pre-occupation with 'form' and 'correctness' inherent in the product approach.

Hairston (1982:78) details some further flaws in the product paradigm as she states that, 'proponents of the product approach apparently viewed the composing process as linear, proceeding systematically from prewriting to writing to rewriting'. It is believed that the product approach limits the writers to a single production of text as opposed to the multiple rewrites allowed in process writing, and while allowing for a certain amount of revision; product writing seriously underestimates the importance of rewriting generally. Johnston (1987) says that in the product classroom, the teacher is not only pre-occupied with grammatical accuracy, but also acts as a judge of students' writing rather than a facilitator.

The above, unfortunately, is a scenario which continues to influence most classroom practices today. Nowadays, however, researchers into writing feel that there is more to writing than the product. The question has shifted into more fundamental cause and effect dimensions. Hayes, 1996; Cox, 2002; Sunflower, 2006; Urbansky, 2006 and a host of other authors note that there is now a widespread recognition that, writing is a process, which involves several identifiable steps or stages. 


\section{Writing as a Process}

Modern understanding now views writing as a process. According to Jordan (1997), the process approach was developed by way of reaction to the confines presented by the product approach. The idea that children needed to experience the writing and composing of their own texts was alien to these earlier methods (Wyse and Jones, 2001). There was also a lack of understanding of the ways that all writing is created as part of a process.

With this approach, the focus of writing instruction shifted from the product to the process. The process of writing refers to what writers do which Graves (1996) describes as having five stages which are brainstorming/pre-writing, drafting, revising, editing and publishing. Again, a common assumption is that the process approach empowers its students, by enabling them to make decisions about the direction of their writing through discussions, tasks, drafting, feedback and informed choices, thus encouraging them to be responsible for making improvements themselves (Jordan 1997; Urbanski 2006; Frederickson 2003).

Generally, writing is seen as a process in which students are given time to think about and discuss their ideas on a specific topic, to write a draft or framework of what they want to say, to discuss this again and then to write a more detailed account (Kilfoil and der Walt, 1997:252). The approach has also been schematized by White \& Arndt (1991) to show the cyclical and recursive nature of writing.

Terms like brainstorming, drafting, revising, editing and publishing are useful for talking about the parts of the writing process, which do not necessarily occur in a fixed order for individual writers in specific situations (Graves, 1996). Also, in the process approach, the students do not write on a given topic in a restricted time and hand in the composition for the teacher to 'correct' - which usually means to find errors. Process writing enables learners to explore a topic through writing, showing the teacher and each other their drafts, and using what they write to read over, think about and move them on to new ideas (Meriwether, 1997). A student should be given the time for the process to work, along with the appropriate feedback from readers such as the teacher or other students. This would enable the student to discover new ideas, new sentences, and new words as they plan, write a first draft and revise what they have written for a second or subsequent drafts depending on their level of competence. Finally, it is believed that the process approach to writing is especially effective for learners of English as L2. It also lends itself to the student-centred learning supported by the communicative approach to the teaching of English as recommended in the Botswana junior secondary education syllabus (Republic of Botswana, 2008).

\section{The Composing Process}

In composing, certain distinctions have been drawn from several studies. Myers (1983) highlights that freshmen who engage in pre-writing consisting of dyadic conversation compose better essays. Cox (2002) also says that prior discussion results in writing that is longer, has more subordination, and has fewer common sentence errors. Writing an effective composition requires a search for information, an incubation period during which thoughts can be 
developed, writing and often re-writing until the composition presents the intended message to the appropriate audience (Grabe \& Kaplan 1996; Cox 2002; Collins 1998). Taba, Samuel \& Freeman (1964) point out in their work on cognitive development, the necessity for gathering and processing data prior to the final abstraction. This process is also vital to writing: the author needs to search, select and reflect about information, main ideas, supporting information and accurate conclusions or ideas. Skills in structuring sentences, paragraph development, grouping, listing and classifying related ideas, identifying main ideas and logical sequence of ideas, are all important and help students to be effective writers.

\section{Writing at Secondary School Level}

At secondary school level, there are immediate and long term objectives for writing. Extended writing or composition writing is taught to enable students to develop writing skills to cope with their academic work, as well as develop functional writing skills to manage the type of writing needed both inside and outside the school situation. Students at this level depend to a large degree on extended writing skills in examinations, and the process approach to writing may provide a valuable head start. In the communicative approach to the teaching of English which is recommended and emphasized throughout the junior and senior secondary school (Republic of Botswana, 2008; 2000) English syllabi, writing is seen as a process. Students are guided to plan, draft and revise their writing and are also encouraged to 'learn to write' as opposed to 'writing to learn' (Tribble, 1996).

Consequently, writing activities at the secondary school level imply that students will have to write for examination purposes, as well as for social and economic purposes and graduate on to academic writing of the type they are going to encounter at post-secondary level and in life outside school. All the above factors have the potential to increase students' motivation for writing. Apart from concentrating on forms of writing that have a practical value to students at this stage; the aims of the basic education and social goals of Botswana for each citizen would be met at personal, social and global levels.

\section{The role of the teacher in process writing}

Leki (1990), talks about the role of the teacher as real reader (audience), coach and evaluator. Criticism of the way teachers respond to students' compositions arises from the fact that they seem to concentrate more on their role as evaluators and judges and do not coach. This means that teachers are seen to be judging students' work rather than guiding students through their writing. In process writing, the outcome or product of the writing becomes of a secondary concern and the teacher becomes a facilitator in providing formative feedback during the process of each student's writing. Teacher feedback given is incorporated during the process as opposed to the traditional system of assessment that focuses on the final written product. A system of assessment that focuses only on the final written product provides unclear feedback on what students are capable of doing as writers (Kasule \& Lunga, 2010). 


\section{Findings and Discussions}

It was found that the teachers' approach to teaching writing was mainly product oriented and that their method showed lack of value/importance placed on writing and creativity as a skill. The teachers did not seem to see the future benefits of the development of their students' writing skills. Composition teaching was probably done just to go through the motions. The teachers' lessons were uninspired, as they showed no passion for the activity. These were reflected in the way the teachers handled the teaching of composition writing in their classrooms as well as their penchant to teach composition writing as homework to their struggling students citing time limitations as well as large class size (about forty students in a class).

\section{Product Approach to Writing}

The teachers in this study focused on the evaluation of the finished product, and awarded number grades to students without evaluating any aspects of the process or the various stages of the writing. Furthermore, evidence from the teachers' evaluation suggested that the focus neglected the content/meaning of the students' writing and concentrated on form and surface level errors of spelling, punctuation and organization. A common characteristic of the product oriented paradigm is that the teacher is not only pre-occupied with grammatical accuracy, but also acts as a judge of students' writing rather than a facilitator. This gave rise to teachers making such negative comments as, 'Mind your grammar', 'Pay attention to your spelling' and so on without much comment on meaning/communication.

The three teachers observed moved in the order of prewriting, drafting and writing of the final copies. There was very little attempt on their part to let students understand that writing is recursive and that they could write as many copies as possible in order to produce an excellent piece of text. Even the students when asked what they normally do in a composition writing lesson, responded to indicate a linear view of writing:

We discuss the topic in a group and after that we make a draft and correct the mistake in the draft and copy them into our composition notebooks.

We work in groups to do the following:

\section{Brainstorm}

Arrange points

Make a draft

Write the final composition.

\section{Writing on a given topic/inappropriate topic}

The three teachers gave students pre-determined topics to work on. Examples of the topics included, 'The day I will never forget, 'A view from my bedroom window' and 'An April Fool's joke that got me into trouble' and so on. There were no indications that the topics were related to a previous topic of discussion or if there were, there was no allusion or reference that might help the students to articulate the requirements of the task. Besides, the topics appeared 
to be culturally inappropriate in some cases. Sometimes, the view from the bedroom may be just another house or somebody else's wall or compound. Also, the idea of 'April Fool' may be a bit alien. The teachers just assumed that the students understood.

\section{Students' Inability to Compose}

Evidence of students' artifacts, and students' interviews showed that they had serious problems with composition writing. The type of writing students did was physical, rather than cognitive. This was shown in the students' difficulties with surface level errors such as spelling, punctuation and paragraphing. In fact, students were failing to communicate in any effective ways in writing. It was clear that many of the students lacked understanding of the topics and/or ideas to express them. Besides, students were limited in their use vocabulary and even substituted with the L1 in some cases. For instance, in writing about, 'Abuse' a student wrote: 'He always eat the money' meaning, 'He spends the money meant for the upkeep of the family'. On the topic, 'A view from my bedroom window', a student showed lack of communication when he wrote, 'I have like the view that my Mother should buy bigger window to see lot of things than that I have seen.'

Again, the lack of adequate vocabulary ensured that students wrote paragraphs of a few lines in their compositions. It was also noted that the teachers in all the cases did not offer helpful feedback to the students during the writing to ensure that they produced a meaningful piece of text. The minimal feedback the teachers gave was usually after the final draft has been written and it is too late for the students to incorporate these in their writing.

\section{Focus on Surface Level Errors}

Feedback given to students focused on surface level features of spelling, punctuation and so on, which did not enhance students' composing skill. As the main focus was on structure as opposed to content/meaning, the students' compositions were sparse and mostly meaningless, as attested to by the teachers themselves who observed that their students lacked communication, grammar and vocabulary skills. This lack of vocabulary resulted in the mother tongue interference noted by the teachers in my interview with them. Intentionally or not, the message to the students was that their inability to write effectively was largely due to spelling, punctuation, and grammar errors, rather than the core issues of communication and meaning. It was not surprising that students attributed their inability to write effectively to spelling and grammar as in the following interview responses:

I have problems with composition writing because of the spelling - - and not arranging the composition well.

The problems I have with composition writing are spelling and using of punctuation marks. Definitely, there is more to composition writing than the mere issues of spelling and punctuation. 


\section{Lack of Motivation to Write}

The constructivist theories describe how learning should happen and is associated with pedagogic approaches that promote active participation by considering such issues as the nature of the learner, the nature of the learning process and the motivation for learning. Such factors as the unique needs, background and complexity of the learner should be taken into account in the teaching and learning process. Apparently, these factors were largely ignored in the pedagogical practices pertaining to the teaching of writing. This oversight on the part of the teachers contributed a lot to the apathy and lack of motivation shown by the students in learning composition writing. This was evident in the interviews with the students in the following responses:

Thinking too much about what to write makes me have a headache. I'm not able to understand the topic and sometimes get my spelling wrong.

Writing about things that you haven't seen or done. It is too abstract for me.

The statements above suggest feelings of frustration and helplessness, which are brought on by the inability of the students to achieve success in their writing attempts and the teachers' methods that did not give them the required help or confidence engender confidence in their writing.

\section{Time Constraints}

It was evident that both the students and teachers were constrained by time in which to do the writing as well as the wrong perception by the teachers that the writing can only be done in one lesson. As a result, all the composition lessons observed were completed as homework by the students. Another dimension to the students' difficulties was the perception that taking much time to write a composition was a sign of failure on their part. On the contrary to this view, adequate time is a feature of the teaching of writing - time to think about the topic, time to research, time to write and re-write, until one becomes satisfied with the final product. Unfortunately, students and teachers apparently failed to utilize the opportunity of process writing to fulfill their tasks satisfactorily.

The lack of the use of time to develop students' writing skills led to the next finding.

\section{Lack of adequate supervision of writing}

The three teachers assigned the composition writing activity to students as homework after the initial prewriting activities of discussion of topics and brainstorming in groups. This may not be a bad thing to do, but from the difficulties of composing experienced by many of the students, it is apparent that they needed more teacher attention and supervision in developing writing skills than leaving them to do the writing on their own. In this instance, composition writing outside the classroom setting gives the teacher very little opportunity to articulate students' difficulties in order to address them.

\section{Composition taught as 'isolated' events}


It was evident in this study that not much writing of the extended type was being done as the three teachers managed to teach only five lessons of composition writing among them for the school term. It was observed that composition writing was limited to 'isolated' and infrequent activity done once in a while within a specified period of eighty (80) minutes or two periods of forty minutes each. Moreover, it was taught only once or twice in a school term. Also, the interactive and integrated activities associated with writing were not encouraged or developed long enough for students to benefit from the process. As a result, students dreaded writing lessons. On the part of teachers, there was the feeling that composition writing was a 'chore' to be attended to once in a while. From what was observed, composition teaching and learning was dreaded by both the teachers and the students. Some students reported that they get scared when they are asked to do composition writing.

\section{Assessment of the written product}

Another related issue that came out of the study was the mode of assessment of writing. Holt \& Willard (2000) emphasize the concept of dynamic assessment in which the interactive nature of learning is extended to assessment. It was noted in this study that the assessment of the writing was impersonal and of little help to learners. The teachers mostly emphasized surface level errors or mechanics of spelling, punctuation and grammar and ignored the areas of content/communication which has to do with communicating effectively. In addition, the three teachers largely awarded almost meaningless number grades to students' writing. Where the teachers offered comments on students' performance, they were not very helpful. Comments, such as, 'Very good,' and, 'Excellent, keep it up,' sound vague. It should indicate what the student did that was particularly good. It should also indicate what the students could have done better to improve the writing. Awarding number grades and meaningless comments is a traditional form of assessment that does not help learners to acquire the necessary writing skills or motivation. New and more effective trends dictate that learners are respected as unique individuals, and that teachers act as facilitators who promote learning and not as judges of students' writing.

\section{Recommendations}

\section{The Reading/Modeling Approach}

On writing effectively in English, it has been argued that reading has an important role to play. In other words, possession of the basic skills of reading can enhance the skills to compose and write (Ross \& Roe, 1990). Sovik (2003) believes that reading and writing, support, complement and contribute to each other's development. Other authors such as Cox (2002) and Tierney \& Leys, (1984) rationalize that both reading and writing should be taught together. In fact, Heller (1995) and Ross \& Roe (1990) contend that the processes involved in learning both skills are the same.

A combination of reading/writing or modeling and process approaches is an option that is worth considering. In its simplest definition, modeling in composition writing refers to a situation whereby reading is related to composition writing activity. The reading here is used to 
start students off in their writing or to provide a context, an example or prior knowledge for the new information or writing that the students need to do.

Reading or modeling (McCann \& Smagorinsky, 1988; Irwin \& Doyle, 1992) in writing has been looked at from different perspectives. Meriwether (1997) and Nunan (1999) look at it from a product oriented perspective when linked to extended writing. Escholz (1980:63) defends the use of models in composition writing as highlighted below:

'Certainly few people will take exception to the general rule that one good way to learn to write is to follow the example of those who can write well. - - - professional writers have long acknowledged the value of reading; they know that what they read is important to how they eventually write.'

Furthermore, White \& Arndt (1991) see modeling as beneficial since it explores the link between reading and writing to improve students' writing skills. In other words, reading can be used to prepare learners for more realistic forms of writing. Also, writing activities in this context can provide a basis for integrated learning through reading and writing. Modeling can be used as a support or scaffolding technique to help L2 learners who are having the type of difficulties highlighted in this study to develop their writing skills. It is believed that the vocabulary students see in their readings usually manages to crop up in their writing and that combining reading with writing provides the writer with the rich potential of the language needed when the situation arises. In addition, it enables students to get the exposure and vocabulary needed to express themselves in the L2 context.

\section{Process Writing}

The exposure initiated in the modeling stage can be followed with process writing activities based on agreed topics from the reading/modeling activities. It has been proven that the process approach in writing is beneficial to L2 language teaching and learning situations and this has to be exploited. In teaching composition skills, the teacher is concerned with the student's ability to develop clear ideas and to organize and elaborate on them. At this point, the recursive nature of writing should be emphasized and students are encouraged to evaluate and make any necessary changes that will improve the writing during and not after the process, something that was not observed to have been encouraged as often as it should in this study. It is believed that if teachers interact with students during the entire writing process, students will have positive feedback and an opportunity to make improvements during each step of the process. When students write and the teacher reacts, the student can decide on changes before the final writing. As a result, only minor changes may be necessary for them to produce a piece of writing. Also, the situation where teachers complain about the headache of marking errors would be minimized, as most of the errors would have been eliminated during the process.

Again, the teachers in this study complained about having to cope with very large class sizes. This is common to many developing Anglophone African countries, of which Botswana is one. 
Policy makers may have to address this, somehow, legitimate concern in order to foster effective language instruction for the realization of educational and social goals of the country.

\section{Future Research}

The above recommendations are just aspects of the options available to address the writing problems of L2 learners at the junior secondary school level in Botswana. The possibilities are numerous and cannot be exhausted in this write up. Perhaps future research should focus on the type of writing/creative writing students do at the primary school level to further ascertain the sources of students' composition writing difficulties.

\section{Conclusion}

The teaching and learning of ESL poses many challenges especially in composition writing at the junior secondary level in Botswana as well as in other similar contexts. The need to explore various options and strategies to overcome the challenges is imperative. Important measures should also be taken to improve writing instruction in schools such as the provision of better equipped libraries, relevant textbooks and materials for teaching language, organization of writing workshops, refresher courses, and remedial teaching of writing to students with severe cases of deficiency. After all, an important aim of literacy is to develop individual abilities to communicate effectively in national and global contexts.

\section{References}

Collins, J. L. (1998). Strategies for Struggling Writers. New York: The Guilford Press.

Cox, C. (2002). Teaching Language Arts. Boston: Allyn \& Bacon.

Escholz, P. A. (1980). The prose models approach: Using products in the process. In Timothy,

R. D. \& Ben, W. M. (Eds.). Eight approaches to teaching composition. Urbana, IL: National Council of Teachers of English.

Frederickson, E. F. (2003). A New World of Writers. New York: Peter Lang Publishing Inc.

Fuller, B. \& Snyder, C. W. (1990). Colourful variations in the teaching practice? In Snyder, C. W. \& Ramatsui, P. T. (Eds.). Curriculum in the Classroom. Gaborone, Botswana: McMillan Botswana, 57-71.

Grabe, W. \& Kaplan, R. B. (1996). Theory and Practice of Writing. London: Longman Graves, D. (1996). Writing: Teacher and Children at Work. Portsmouth, NH: Heinemann Publishers.

Hairston, M. (1982).'The winds of change: Thomas Kuhn and the revolution in the teaching of writing'. College Composition and Commnunication 33 (1), 76-88.

Hayes, J. R. (1996). A framework for understanding cognition and affect in writing. In Kevy, C. M. \& Randsdell, S. (Eds.). The Science of Writing. Mahwah, NJ: Erlbaum, 3 -30.

Holt, D. G. and Willard-Holt, C. (2000). Lets get real - students solving authentic corporate problems. Phi Delta Kappa, 82 (3), 243-246.

Heller, M. F. (1995). Reading-Writing Connection: From Theory To Practice. White Plains, NY: Longman. 
Honey, J. (200). Language and Social Studies Teaching. In Adeyemi, M. B. (Ed.). Social Studies in African Education, Gaborone, Botswana: Pyramid Publishing, 25-33.

Irwin, J. W. \& Doyle, M. A. (1992). Reading/writing connections: Learning from research. Newark, DE: International Reading Association.

Jordan, R. R. (1997). English for Academic Purposes. Oxford: Oxford University Press.

Johnston, B. (1987). Assessing English: Helping Students to Reflect on their Work. Milton Keynes: Open University Press.

Kasule, D. \& Lunga, V. B. (2010). Attitudes of second language students towards self-editing their own written texts. Journal of the Reading Association of South Africa, Vol. 1(1), 61-72.

Kilfoil, L. and van der Walt, C. (1997). Learn 2 Teach: English Language Teaching in a Multilingual Context, Pretoria: J. L. van Schaik Publishers.

Leki, I. (1990). Coaching from the margins: Issues in written response. In B. Kroll (Ed.). Second Language Writing: Research Insights for the Classroom, 57-68.

Lyons, J. (1981). Language and Linguistics: An Introduction. Cambridge, England: Cambridge University Press.

McCann, T. \& Smagorinsky, P. (1988). Prospectus for composition textbook. Unpublished manuscript, Department of Instructional Leadership and Academic Curriculum. University of Oklahoma, Oklahoma City.

Mckay, S. L. (2004). Western culture and the teaching of English as an international language. English Teaching Forum, 42 (2), 10-15.

Meriwether, N. W. (1997). Strategies for writing successful essays. New York: NTC Publishing.

Mooko, T. (1996). An investigation into the impact of guided peer feedback and guided self-assessment on the quality of compositions written by secondary school students in Botswana. Unpublished Doctoral Dissertation, University of Essex, England.

Myers, M. (1983). Theory and Practice in the Teaching of Composition: Processing, Distancing and Modelling, Urbana, IL: National Council of Teachers of English.

Nunan, D. (1999). Second language teaching and learning. London: Heinle \& Heinle

Pongweni, A. (1999). The English Language Learning experiences of post-O-level and mature age applicants to the University of Botswana. Marang: Language, Literature and Society: Proceedings of the Conference in Honour of Bessie Head, Gaborone: University of Botswana, 169-184.

Prophet RB 1990. Experience, language, knowledge and curriculum. In CW Snyder and PT Ramatsui (Eds.). Curriculum in the Classroom, Gaborone: Macmillan, 109-119.

Republic of Botswana (2008). The Revised Three-Year Junior Secondary Syllabus (English). Gaborone, Botswana: Government Printer.

Republic of Botswana (2008). Junior Certificate Examination: Principal Examiner's ReportPaper 3. Gaborone: Government Printers

Republic of Botswana (2008). Junior Certificate Examination: Principal Examiner's ReportPaper 2. Gaborone: Government Printers

Republic of Botswana (2005). JC Examiners' Report: English Paper 2, Gaborone: Government Printers 
Republic of Botswana (2002) The Nine-Year Basic Education Programme. Gaborone: Government Printers.

Republic of Botswana (2001). JC Examiners' Report: English Paper 2, Gaborone: Government Printers

Republic of Botswana (2001). Report on the Monitoring of Learning Achievement. Gaborone: Examinations and Testing Division.

Republic of Botswana (2000). Senior Secondary English Syllabus. Gaborone, Botswana: Government Printers.

Republic of Botswana (1997). Long Term Vision for Botswana, Vision 2016: Towards Prosperity for All. Gaborone: Government Printers.

Republic of Botswana (1994). Revised National Policy on Education. Gaborone: Government Printer.

Republic of Botswana (1977). National Policy on Education, Government Paper No. 1. Gaborone: Government Printer.

Richards, J. C. and Rogers, T. S. (1995). Approaches and Methods in Language Teaching. Cambridge: Cambridge University Press.

Rowell, P. M. (1991). Communicating in the classroom: An interpretative study of two junior secondary schools. Unpublished Report submitted to IEES Research Foundation. New York: University of Albany.

Ross, E. and Roe, B. D. (1990). An Introduction to Teaching language Arts. Chicago: Holt, Rinehart and Winston.

Silva, T. (1993). Towards an understanding of the distinct nature of L2 writing: the ESL research and its implications. Journal of Second Language Writing, 2, 657- 677.

Sovik, N. (2003). Writing: On Developmental Trends in Children's Manual and Composition Writing. Hauppauge, NY: Nova Science Publishers.

Sunflower, S. B. (2006). Really Writing: Ready-to-use Writing Process Activities for the Elementary Grades. San Francisco, CA: Jossy Bass.

Taba, H., Samuel, L. and Freeman, F. (1964). Thinking in Elementary School Children: Cooperative Research Project, Number 1574. Washington DC: Research Programme of the Office of Education, US Department of Health, Education and Welfare.

Tierney, R. J. and Leys, M. (1984). What is the value of connecting reading and writing? In Bruce, T. P. (Ed.), Convergences: Transactions in Reading and Writing. Urbana, IL: National Council of Teachers pp. 38-45.

Tribble, C. (1996). Writing. Oxford: Oxford University Press.

Urbanski, C. D. (2006). Using the Workshop Approach in the High School English Classroom: Modeling Effective Writing, Reading and Thinking Strategies for Student Success, Thousand Oaks, CA: Corwin Press.

White, R. and Arndt, V. (1991). Process Writing. London: Longman.

Williams, J. G. (2003). Providing feedback on ESL students' written assignments. The Internet TESL Journal, IX (10), 123-129

Wyse, D. and Jones, R. (2001). Teaching English Language and Literacy. New York: Routledge Palmer Tribble, C. (1996). Writing. Oxford: Oxford University Press. 
